\title{
Relative Resistance or Susceptibility of Landscape-suitable Elms (UImus spp.) to Multiple Insect Pests
}

\author{
Daniel A. Potter and Carl T. Redmond
}

\begin{abstract}
The National Elm Trial is a cooperative project to assess landscape suitability of Dutch elm disease-resistant elms (Ulmus spp.) in various regions of the United States. Researchers evaluated 20 cultivars of American, Asian, and hybrid elms for relative resistance or susceptibility to multiple insect pests in central Kentucky over seven years. Ratings for Japanese beetle, European elm flea weevil (EEFW), and several other pests were previously published. This paper reports data for seven additional pests, including honeydew-excreting scale insects (Parthenolecanium corni, Eriococcus spuria, and Pulvinaria innumerabilis), leaf-distorting woolly elm and woolly apple aphids (Eriosoma spp.), elm cockscomb gall aphid (Colopha ulmicola), and an invasive weevil (Oedophrys hilleri) not previously known to damage elms. Rankings for all 12 of the monitored pests are summarized. Most $U$. americana cultivars were relatively susceptible to the scale insects and likewise, Eriosoma spp. and C. ulmicola only infested the American elms. $O$. hilleri is a new state record for Kentucky. Its adults, active in mid- to late summer, chewed notches in edges of leaves. Cultivars of the Asian species U. parvifolia and U. propinqua, including 'Athena Classic Lacebark', 'Everclear Lacebark', 'Emer II Allee', and 'Emerald Sunshine' were top-rated for insect resistance. They were nearly pest-free except for foliar damage by EEFW, to which nearly all elms were susceptible. Insect resistance should be considered when re-introducing elms to urban landscapes. The data may help city foresters, landscapers, and others re-introducing elms to urban landscapes to select relatively pest-free cultivars requiring minimal inputs for insect control.

Key Words. Cockscomb gall Aphid; Dutch Elm Disease; Eriococcus spuria; Eriosoma spp.; European Elm Flea Weevil; National Elm Trial; Oedophrys hilleri; Parthenolecanium corni; Ulmus spp.
\end{abstract}

The National Elm Trial (NET) is a cooperative effort to evaluate Dutch elm disease (DED) resistant, commercially available American and hybrid elms (Ulmus spp.) for horticultural characteristics and suitability for use across a range of environmental conditions in the United States (Jacobi et al. 2009). It seeks information to support successful return of American and hybrid elms to streets and landscapes. Large replicated field plots were planted in Kentucky and 14 other states. Since 2006, researchers have been evaluating 20 elm cultivars of differing parentage at the Kentucky site for relative susceptibility or resistance to multiple insect pests. Some of the pests cause minor aesthetic damage whereas others have a severe enough impact to potentially reduce sustainability of established trees.

Elms, particularly the stately American elm (Ulmus americana) were once a dominant component of the urban forest throughout much of North America (Hubbes 1999). Dutch elm disease, caused by the fungus Ophiostoma ulmi and vectored by elm bark beetles (Coleoptera: Curculionidae: Scolytinae), had already decimated elms in Europe when it was first discovered in the United States in 1930 (Hubbes 1999). By 1977 , pandemics of DED had killed most of the original elm population in the eastern United States (Merkle et al. 2007). Efforts to develop hardy DED-resistant American and hybrid elms have been underway for many years (Smalley and Guries 1993; Merkle et al. 2007). Although straight selection by inoculation screening yielded several commercial American elm cultivars with partial DED-resistance (Merkle et al.
2007), all of them may become infected (Hubbes 1999). The main sources for DED resistance genes are Asian elm species, such as $U$. parvifolia, U. pumila, U. propinqua, U. japonica, U. wilsoniana, and others (Smalley and Guries 1993, Hubbes 1999). The DED fungus likely originated in Asia (Brasier and Mehrotra 1995), so genotypes having Asian provenance have had longer to develop resistance. A number of DEDresistant hybrid elms have been developed from combinations of Asian and, to lesser extent, European genotypes (Smalley and Guries 1993). Their growth habit, leaf size, and hardiness vary across different regions (Smalley and Guries 1993).

Resistance ratings and biological observations from the Kentucky portion of the NET were previously reported for Japanese beetle (Popillia japonica), pouch gall aphids (Tetraneura nigriabdominalis), European elm flea weevil (Orchestes alni), and the leaf miners Agromyza aristata and Kaliofenusa ulmi (Condra et al. 2010). Since then additional pest species have colonized the tree plots. Researchers report here on relative resistance to seven additional insect pests including three species of honeydew-excreting soft or felt scales, two leaf-distorting woolly aphid species, aphid cockscomb galls, and an invasive leaf-notching weevil not previously reported as a pest of elms. By late summer 2012, tree loss from drought and other causes had reduced the original five replicates to only 2 to 3 trees of some cultivars; then a construction project that autumn necessitated transplanting trees from a portion of the plot. It is timely, therefore, to summarize findings to date from the Kentucky NET and rank the 
elms based on their relative susceptibility or resistance to all 12 pests evaluated since 2006. That summary, too, is reported herein.

\section{METHODS AND MATERIALS}

The main study site was an open, grassy area on Maury silt loam soil adjacent to the Arboretum and State Botanical Garden

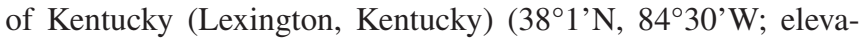
tion $302 \mathrm{~m}$ ). Five replicates of 20 elm cultivars, including North American, Asian, and European species and hybrids (Table 1) were planted in a randomized complete block in rows spaced $7.6 \mathrm{~m}$ apart, with $7.6 \mathrm{~m}$ between trees within rows and about $50 \mathrm{~m}$ between replicates. Seventeen cultivars were planted in spring 2005; three others were planted in randomized spaces left in each block in spring 2006 or 2007. The trees were obtained from nurseries as bare-root transplants and ranged from 1.5 to $2.4 \mathrm{~m}$ height at time of planting. They were staked, watered as needed, and mulched over grass that had been killed with glyphosate herbicide. Cultivar names and provenance are summarized in Table 1. Leaf characteristics (mean area, number per shoot, pubescence) were previously summarized (Condra et al. 2010).

\section{Pest Resistance Evaluations}

Three species of sap-feeding scale insects colonized trees at the study site. Their numbers were assessed by inspecting each tree on multiple dates. For some of the taller trees, observers stood on a step ladder or truck tailgate to reach and sample sufficient numbers of representative branches.

European fruit lecanium, Parthenolecanium corni (Hemiptera: Coccidae), was abundant enough to provide data from three growing seasons (2010-2012). Five twigs were randomly selected from throughout the canopy of each tree; then beginning at the previous year's node the number of adult scales was counted on a $30-\mathrm{cm}$ long section of each twig. Data were standardized to number of scales per $1.0 \mathrm{~m}$ of twig length. Counts were taken over 2-3 days in early July in 2010 and 2011, and in June 2012.

European elm scale, Eriococcus spuria (Hemiptera: Eriococcidae), was abundant enough to census in 2011 and 2012. Adult scales were counted on five $30 \mathrm{~cm}$-long twigs per tree as previously described. In addition, because E. spuria also infested bark of the trunk and scaffold limbs, two observers standing on opposite sides of each tree inspected bases of those branches and main trunk of each tree to $2 \mathrm{~m}$ height, and counted scales spotted in 30 seconds, taking care not to count particular scales more than once. Counts from the two methods were pooled for analysis. Sampling dates were the same as for P. corni.

Cottony maple scale, Pulvinaria innumerabilis (Hemiptera: Coccidae), was first noticed on the trees in 2012. Two observers slowly circled each tree on June 7-8 and together counted all of the distinctive white scales through the canopy.

A mottled gray, leaf-notching weevil was found feeding on elms at the study site in 2010 (Figure 1). Specimens were sent

Table 1. Elm species hybrids and cultivars evaluated for insect resistance in Lexington, Kentucky, U.S., from 2006 to 2012 with geographical origins and selected leaf characteristics.

\begin{tabular}{|c|c|c|c|}
\hline Species or parentage & Cultivar name & Abbr. & Native range ${ }^{z}$ \\
\hline U. americana & $\begin{array}{l}\text { Valley Forge } \\
\text { Princeton } \\
\text { Jefferson } \\
\text { New Harmony } \\
\text { Lewis \& Clark Prairie Expedition }\end{array}$ & $\begin{array}{l}\text { VF } \\
\text { PN } \\
\text { J } \\
\text { NH } \\
\text { PE }\end{array}$ & N. America [NA] \\
\hline U. parvifolia & $\begin{array}{l}\text { Emer II Allee } \\
\text { Athena Classic Lacebark } \\
\text { Everclear Lacebark }\end{array}$ & $\begin{array}{l}\text { EA } \\
\text { A } \\
\text { E }\end{array}$ & Japan, China, Korea [A] \\
\hline U. propinqua & Emerald Sunshine & ES & Japan $[\mathrm{A}]$ \\
\hline U. wilsoniana & Prospector & PR & China $[\mathrm{A}]$ \\
\hline U. pumila $\times$ japonica & $\begin{array}{l}\text { Morton Plainsman Vanguard } \\
\text { New Horizon }\end{array}$ & $\begin{array}{l}\mathrm{MP} \\
\mathrm{Nh}\end{array}$ & $\mathrm{A} \times \mathrm{A}$ \\
\hline $\begin{array}{l}\text { U. pumila } \times \text { japonica } \\
\times \text { wilsoniana }\end{array}$ & Morton Glossy Triumph & MG & $\mathrm{A} \times \mathrm{A} \times \mathrm{A}$ \\
\hline $\begin{array}{l}\text { U. carpinifolia } \times \text { pumila } \\
\times \text { wilsoniana }\end{array}$ & Morton Stalwart Commendation & MS & $\mathrm{A} \times \mathrm{A} \times \mathrm{A}$ \\
\hline $\begin{array}{l}\text { U. glabra } \times \text { carp. } \times \text { pumila } \\
\times \text { wilsoniana }\end{array}$ & Patriot & PT & $\mathrm{E} \times \mathrm{A}$ \\
\hline U. carp $\times$ parvifolia & Frontier & $\mathrm{F}$ & $\mathrm{E} \times \mathrm{A}$ \\
\hline U. glabra $\times$ carp $\times$ pumila & Homestead & $\mathrm{H}$ & $\mathrm{E} \times \mathrm{E} \times \mathrm{A}$ \\
\hline U. glabra $\times$ carpinifolia & Pioneer & PI & $\mathrm{E} \times \mathrm{E}$ \\
\hline
\end{tabular}

${ }^{\mathrm{z}}$ Parental species (native ranges) not listed: U. carpinifolia (Europe, N. Africa); U. glabra (Europe, W. Asia); U. pumila (Siberia, China, Korea); and U. davidiana var. japonica (China, Japan, Korea). 
to R. Anderson (Canadian Museum of Nature, Ottawa, Ontario, Canada) who identified them as Oedophrys hilleri (Coleoptera: Curculionidae), a new state record for Kentucky. Adults feed on leaves of peach, apple, and other rosaceous plants (Brown and Matthews 2009) but have not previously been reported damaging elm trees. Adult populations were sampled of adults on each tree were sampled on July 11-12 and August 11 in 2011, and on August 8,2012. The first sampling was with a gasolinepowered leaf blower reversed for suction and fitted with a paint strainer in the intake tube. Each tree's canopy was sampled for 60 seconds; samples then were transferred to bags and frozen before counting. For subsequent samples, researchers used a beating sheet $(71 \mathrm{~cm} \times 71 \mathrm{~cm}$, BioQuip, Rancho Dominguez, California, U.S.), striking eight branches (four each in lower and upper canopy) with a stick and counting dislodged weevils.

Two species of foliage-distorting woolly aphids (Figure 1) were abundant enough to evaluate in 2012. Spring feeding by woolly elm aphid, Eriosoma americanum (Hemiptera: Aphididae), causes developing leaves to swell and their edges to curl downward. The aphids feed and reproduce within the leaf rolls. Spring feeding by woolly apple aphid, Eriosoma lanigerum (Hemiptera: Aphididae), results in unsightly rosette-like clusters of deformed leaves at the ends of shoots (Figure 1). Both aphids also cause damage by sucking sap from the host, and by producing honeydew. Incidence of each pest's damage was assessed in early June by two observers who counted all individually-rolled leaves (E. americanum) and rosettes (E. lanigerum) on each tree.

Elm cockscomb gall aphid, Colopha ulmicola (Hemiptera: Aphididae), is a relatively minor pest that induces elongated, raised, irregularly-toothed galls on the adaxial surface of leaves. The gall's shape and reddish color at maturity account for the common name. The leaf galls harden and turn brown after the aphids depart. The number of galls on each tree (to $2.5 \mathrm{~m}$ height) were counted by two observers on July 11-12, 2011, and on June 7-8, 2012.

\section{Statistical analyses and resistance ratings}

Numbers of each pest were compared among cultivars by twoway analysis of variance (ANOVA) and pre-planned single degree of freedom linear contrasts between groups of elm species or parentages. Log or square root transformations were used if needed to meet assumptions of normality and homogeneity of variance. The nonparametric Kruskal-Wallis test was used in cases where ANOVA assumptions could not be met because of all zeroes for some cultivars. Statistix version 9.0 (Analytical Software 2008) was used for analyses. All data are reported as original means \pm Standard Error (SE).

Cultivar means for pests previously monitored (Condra et al. 2010) were averaged across the 2-3 growing seasons each was evaluated and then ranked on a 1-5 scale based on pest density or extent of damage. The most susceptible cultivar(s) always received a 5 rating, and cultivars that sustained no damage or infestation by a particular insect received a 0 rating for that pest. For Japanese beetle defoliation, $0-5$ ratings corresponded to $<10$, $22-20,21-30,31-40,41-55$, and $>55 \%$ cumulative leaf loss, respectively. Tree ratings for the leafminers $O$. alni, A. aristata, and K. ulmi, and for T. nigriabdominalis aphid pod galls were based on numbers of mines or galled leaves per 100 leaves (2006-2008) or per ten 30-cm shoots (2009-2012), with 1-5 ratings generally assigned to cultivars ranked in successive quintiles of the frequency distribution. For those pests first reported on in this paper,
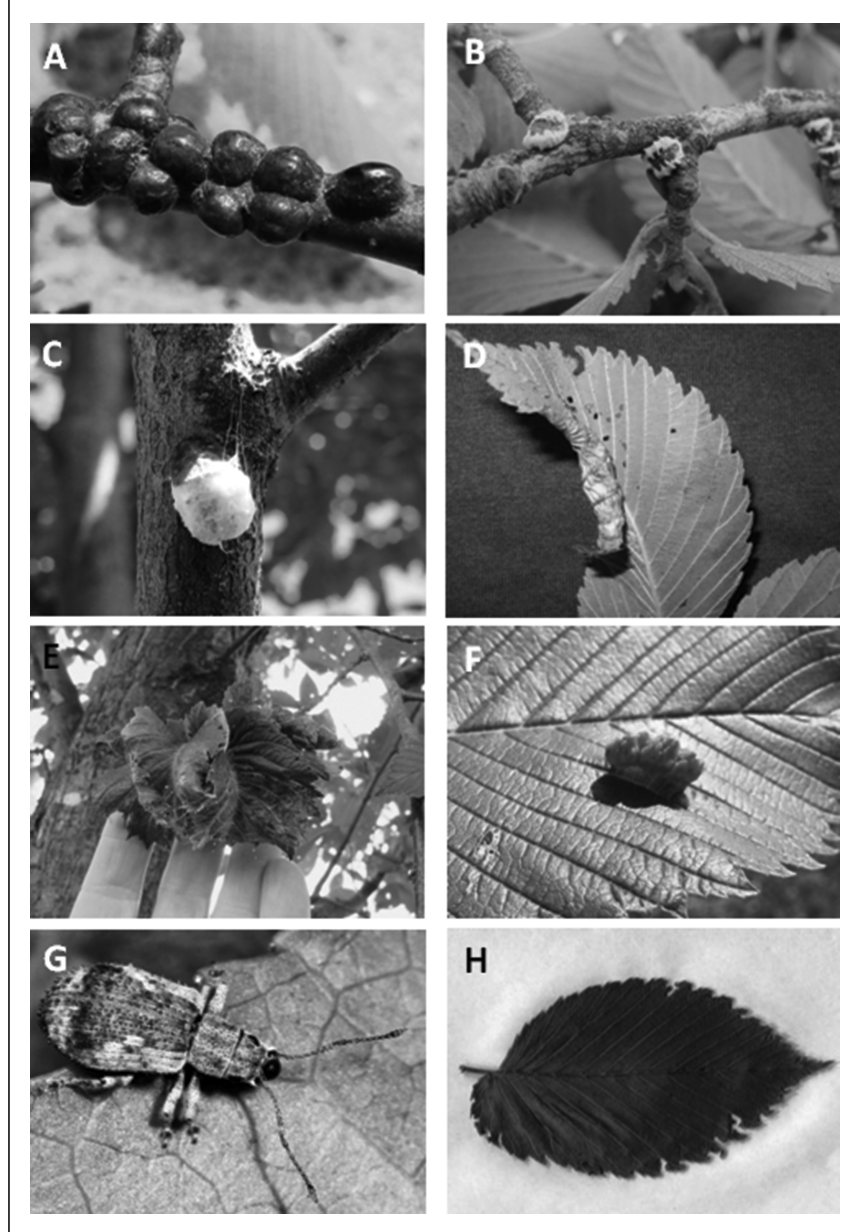

Figure. 1. Insect pests and damage symptoms evaluated in the Kentucky portion of the National Elm Trial from 2010-2012: (A) European fruit lecanium (Parthenolecanium corni), (B) European elm scale (Eriococcus spuria), (C) cottony maple scale (Pulvinaria innumerabilis), (D) woolly elm aphid (Eriosoma americanum), (E) woolly apple aphid (Eriosoma lanigerum), (F) elm cockscomb gall aphid (Colopha ulmicola), (G) Oedophrys hilleri weevil (photo by $S$. Cresswell), (H) leaf notching by $O$. hilleri. See Condra et al. (2010) for images of previously evaluated pests.

cultivar ratings were based on number of European fruit lecanium and European elm scale per $1.5 \mathrm{~m}$ of twig length, or whole tree counts for $O$. hilleri, elm cockscomb gall aphid, wooly elm aphid, wooly apple aphid, and cottony maple scale, as described herein.

For susceptibility/resistance rankings, the study authors considered four of the insect species, Japanese beetle, European elm flea weevil, European fruit lecanium, and European elm scale, as "major" pests because, at least in Kentucky, their impact on heavilyinfested trees and/or problems associated with their honeydew can be serious enough to warrant control. Ratings for those four pests were doubled and then added to the sum of ratings for the remaining eight pests to get overall scores upon which the $20 \mathrm{elm}$ genotypes were ranked for relative susceptibility to insect pests.

\section{RESULTS}

European fruit lecanium and European elm scale were the most abundant scale insects infesting elms at the study site. The former was found almost exclusively on twigs, whereas the latter 
was found on twigs, large branches, and bark of the trunk around the bases of scaffold limbs. The two pests had similar patterns of relative abundance or scarcity across elm species, cultivars, and parentages (Figure 2; Figure 3) and abundance of each differed significantly among the 20 genotypes of elms (KruskalWallis tests, $P<0.001)$. American elms, as a group, were more susceptible than Asian or hybrid cultivars to both scale species (Figure 2; Figure 3). Honeydew accumulation on the more heavily infested U. americana cultivars, such as 'Valley Forge', 'Pioneer', and 'New Harmony' promoted growth of sooty mold and attracted ants and wasps. Scale densities also varied among $U$. americana cultivars in each year (two-way ANOVA, $P<0.01$ ), with 'Jefferson', in particular, having relatively few scales in each of the first two years that the respective species were evaluated. By 2012, however, densities of European fruit lecanium had built up to $>25$ scales per $1.5 \mathrm{~m}$ of twig growth, even on 'Jefferson' (Figure 2). Among hybrid cultivars, 'Patriot' and 'New Horizon' had relatively high densities of both scales.

Cottony maple scale was first observed on some trees in 2012. Densities were low, with no overall differences among cultivars (Kruskal-Wallis, $P=0.50$ ), but as with the other scales, it was mainly found on American elms (Figure 4).

$O$. hilleri adults infested leaves of all 20 elm cultivars (Figure 4). Although there were cultivar differences in each year, the weevil was not consistently more or less abundant on elms of any particular species, parentage, or provenance. Adults were first observed in the trees in June and became more abundant during July and August when many mating pairs were observed.

Leaf distortions from woolly elm aphid and woolly apple aphid were restricted to U. americana (Figure 5). Both Eriosoma spp. were only abundant enough for meaningful comparisons in 2012, when abundance of each differed among $U$. americana cultivars (Kruskal-Wallis tests; $P=0.05$ for rolled leaves with woolly elm aphid; $P=0.04$ for rosette-like clusters with woolly apple aphid). Both pests were especially abundant on 'Princeton' (Figure 6).

Elm cockscomb galls were found only on four American elm cultivars (Figure 5) but their occurrence was sporadic and variable, with detectable cultivar differences only in 2012 (Kruskal-Wallis test, $P=0.04$ ). Cockscomb galls were most numerous on 'Jefferson' (Figure 7).

Cultivars of the Asian species- $U$. parvifolia and $U$. propinqua-were top-rated from the standpoint of insect resistance and nearly pest-free except for EEFW foliar damage, to which nearly all species and cultivars were vulnerable (Table 2). Most $U$. americana cultivars were relatively susceptible to $P$. corni and E. spuria, and to leaf disfiguration by woolly elm and woolly apple aphids. Most hybrid cultivars were susceptible to foliar damage from Japanese beetles. Cultivars varied in relative resistance or susceptibility to the remaining types of pests (Table 2).

\section{DISCUSSION}

Diversifying the urban forest is important because invasive and native pests—-such as emerald ash borer (Agrilus planipennis), Asian longhorned beetle (Anoplophora glabripennis), hemlock woolly adelgid (Adelges tsugae), thousand cankers disease of walnut caused by combined activity of the walnut twig beetle (Pityophthorus juglandis) and a canker producing fungus (Geosmithia morbida), sudden oak death/decline fungus (Phytopthora ramorum), and bacterial leaf scorch

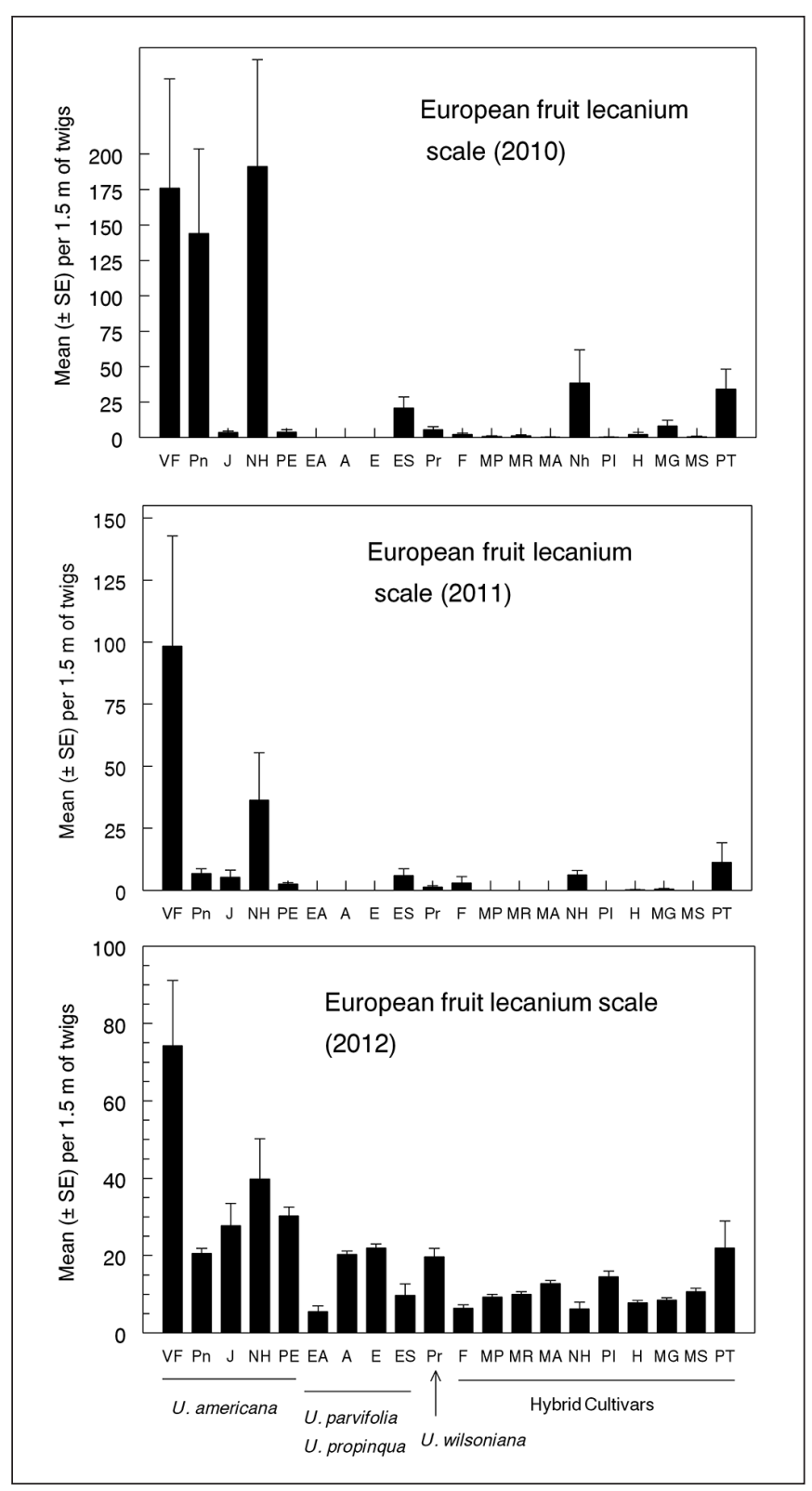

Figure 2. European fruit lecanium relative abundance on elm species and cultivars. Cultivars abbreviations are indicted in Table 1. There were significant cultivars differences each year (KruskalWallis, $P<0.001$ ). Absence of variance (means of zero) for some cultivars precluded parametric analyses in 2010-11. U. americana cultivars as a group were more heavily infested than those having Asian parentage (U. parvifolia + propiqua + wilsoniana), or hybrid cultivars in 2012 (ANOVA, linear contrasts, $P<0.01$ ).

(Xylella fastidiosa) - threaten the health of prevailing tree species (Raupp et al. 2006). Replacement trees ideally should be relatively pest free to reduce need for insecticide treatments. Evaluations to date at the Kentucky NET site provided resistancesusceptibility data for a range of commercially-available Dutch elm disease-resistant elms to 12 different insect pests.

European fruit lecanium and European elm scale are univoltine and of Palearctic origin. Both were especially abundant on certain $U$. americana cultivars, often infesting the same trees. The former is polyphagous, whereas the latter mainly feeds 
on Ulmus spp. (Johnson and Lyon 1988; Dreistadt and Hagen 1994). The results indicate differential susceptibility of Ulmus genotypes to both pests. American elms as a group sustained the highest populations, with certain cultivars

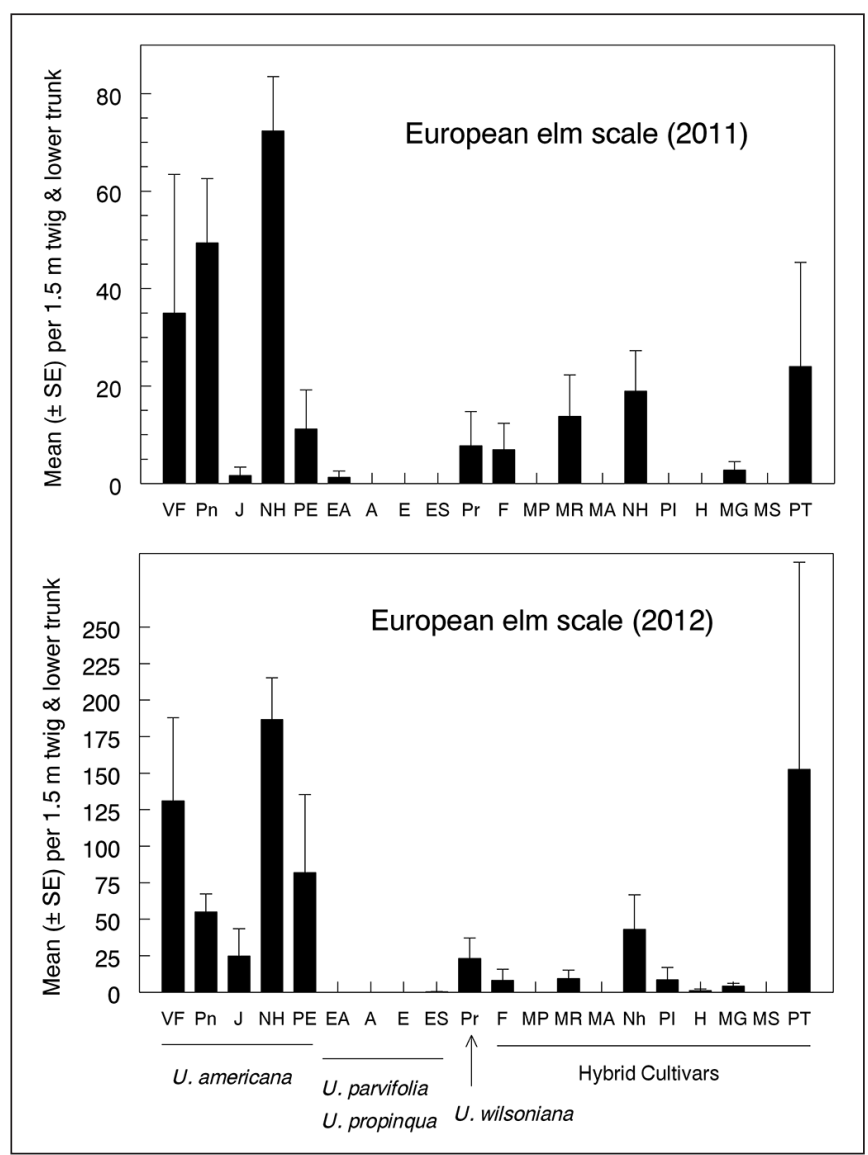

Figure 3. European elm scale relative abundance on elm species and cultivars. There were significant differences among cultivars in each year (Kruskal-Wallis, $P<0.001$ ).

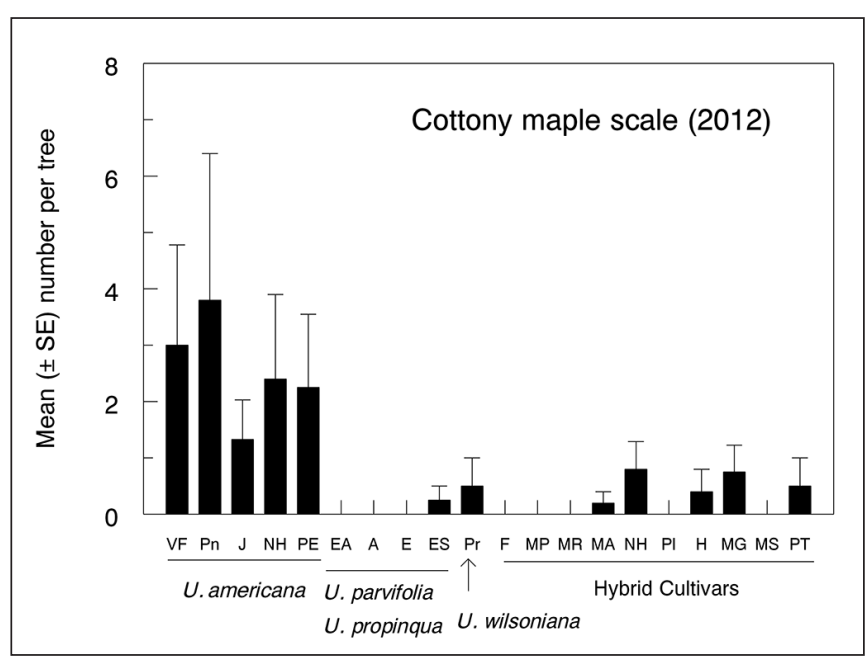

Figure 4. Cottony maple scale whole-tree counts in 2012, the first year it was noted on some trees. Low numbers, high variance, and reduced replication due to loss of some trees contributed to no detectable cultivar differences (Kruskal-Wallis, $P=0.48$ ). (e.g., 'Valley Forge', 'New Horizon') especially susceptible. Cottony maple scale, another polyphagous species, was present at low density but also mainly on American elms. The aforementioned scales cause branch dieback and produce honeydew that favors growth of fungi associated with sooty mold. Falling honeydew can be a significant nuisance under street trees and in parking lots, so highly susceptible cultivars may not be the best choice for such settings. Honeydew also attracts nuisance pests, such as wasps and ants (Hodges and Hodges 2001; Vanek and Potter 2010). Tending by ants can interfere with natural biological control of soft scales on woody landscape plants (Vanek and Potter 2010).

The finding of $O$. hilleri was a new state record for Kentucky. Native to East Asia, the weevil has been reported in the United States from Connecticut to Virginia, Pennsylvania, West Virginia, and Kansas (Brown and Mathews 2009). The only study concerning its biology in North America found larvae and pupae in soil under peach trees, and documented larval damage to roots of peach seedlings and adult feeding on foliage of peach and other rosaceous plants (Brown and Mathews 2009). It has not previously been associated with Ulmus spp. Researchers often saw O. hilleri and EEFW adults and their damage on the same trees. The former are

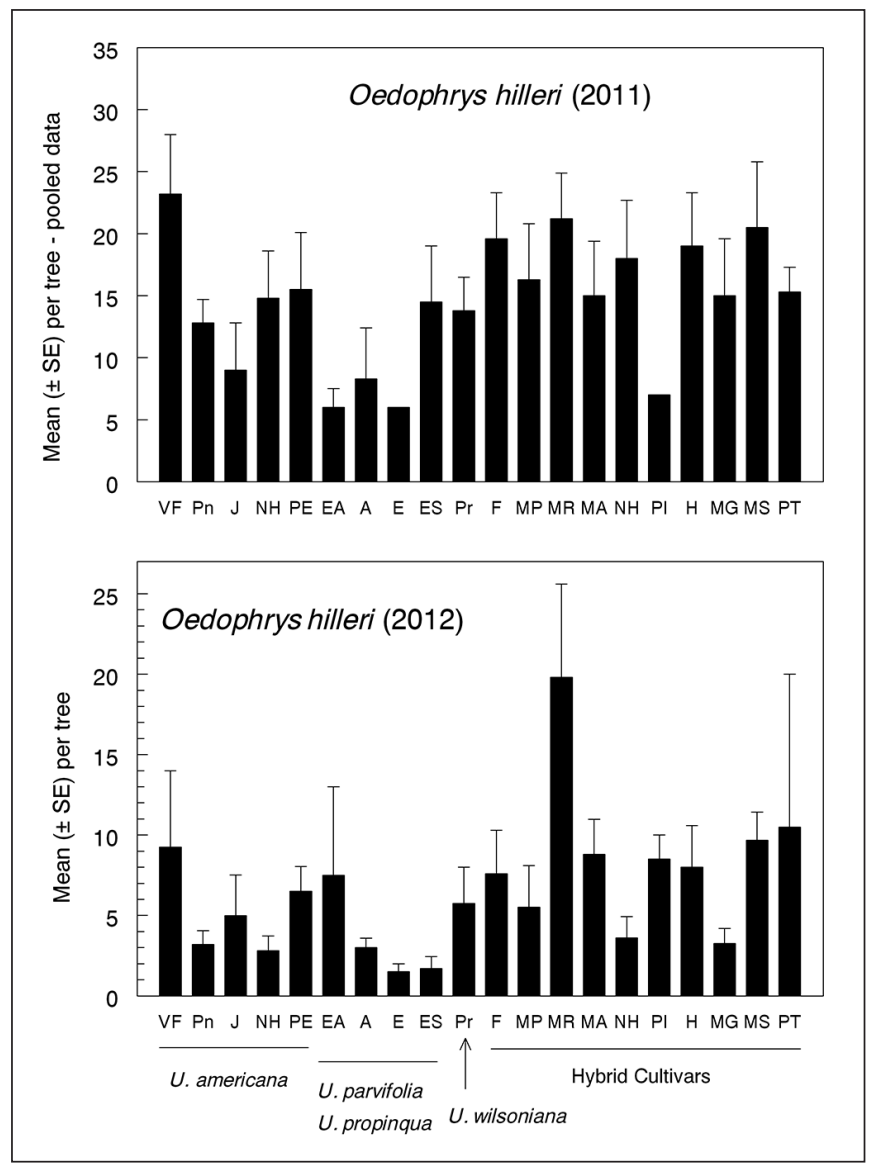

Figure 5. Leaf-notching weevil 0 . hilleri relative abundance on elm species and cultivars. Cultivar differences were significant each year $\left(F_{19,59}=2.54, P<0.01\right.$ in 2011; $F_{19,52}=2.04, P<0.05$ in 2012). Elms with Asian parentage as a group had fewer weevils than either American or hybrid cultivars in 2011 and fewer than hybrids in 2012 (linear contrasts, $P<0.01$ ). 
mottled gray, slow-moving, and notch leaves from their margins, whereas EEFW are reddish brown, active jumpers, and leaves upon which they have fed appear as if riddled with tiny shot holes (Figure 1). EEFW adults feed upon and lay eggs in expanding leaves in April; its larval mines are initiated in late April and completed by mid to late May. The resultant adults cause extensive foliar damage in late May and June, but by July they have nearly disappeared from tree canopies (Condra et al. 2010). O. hilleri adults are most abundant in June and July, as cited here as well as by Brown and Mathews (2010). Their larvae presumably feed on elm roots (see above) but whether or not it impacts tree vigor is unknown.

Woolly elm and woolly apple aphids overwinter as eggs in bark crevices on elms (Johnson and Lyon 1988). Nymphs hatch in spring and migrate to the new growth. Feeding by the maturing female woolly elm aphid and her parthenogenicallyproduced offspring causes a tight leaf edge curl on individual leaves within which the colony develops. Woolly apple aphid feeding induces rosettes of twisted, dwarfed leaves to form at growing tips of shoots (Figure 1). In late spring, a winged generation is produced that flies to summer hosts: Amelanchier spp. for woolly elm aphid, Malus or other rosaceous hosts for woolly apple aphid. Those aphids give rise to another brood of nymphs,

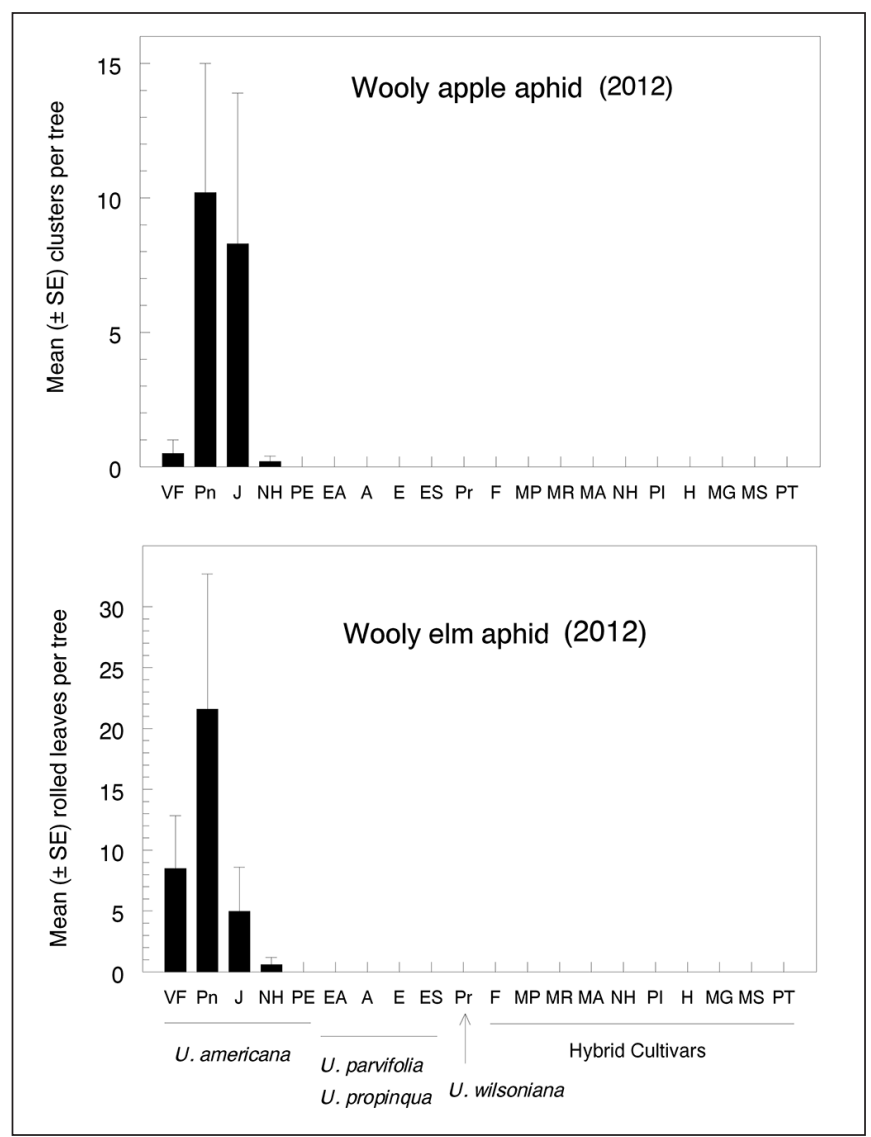

Figure 6. Rolled leaves with woolly elm aphids and rosettes of deformed leaves caused by feeding of woolly apple aphids were restricted to $U$. americana. Within American elms, there were significant cultivar differences in susceptibility to each pest (Kruskal-Wallis, $P \leq 0.05$ ). all females, which migrate to and feed on roots of their summer hosts, and in the case of wooly apple aphid, on aboveground tissues too. Winged females from a sexual generation produced in early autumn fly back to elms to lay overwintering eggs. Both Eriosoma species were found only on $U$. americana, especially 'Princeton'. Although neither is likely to reduce vigor of established elms, the leaf deformities are unsightly enough that highly susceptible cultivars might be unsuited to high-profile sites.

Elm cockscomb gall aphid has a complex life cycle. It induces galls on elm in spring, progeny vacate them to feed on grass roots in summer, and then winged forms return to elms in autumn tolay overwintering eggs around buds (Patch 1910). Although the galls may attract attention, they likely have negligible impact on tree health.

Another pest, elm leaf beetle (Xanthogaleruca luteola), which in Kentucky was common until about 10-20 years ago (authors' observations), was conspicuously absent at the study site. Its populations have also declined elsewhere in the Ohio Valley region (e.g., Gibb et al. 2005).

In summary, although none of the elms in the National Elm Trial are immune to insect injury, they differ in susceptibility to key pests that, if present, could potentially compromise the sustainability of landscape or street trees. Awareness of such differences should help urban foresters and landscapers

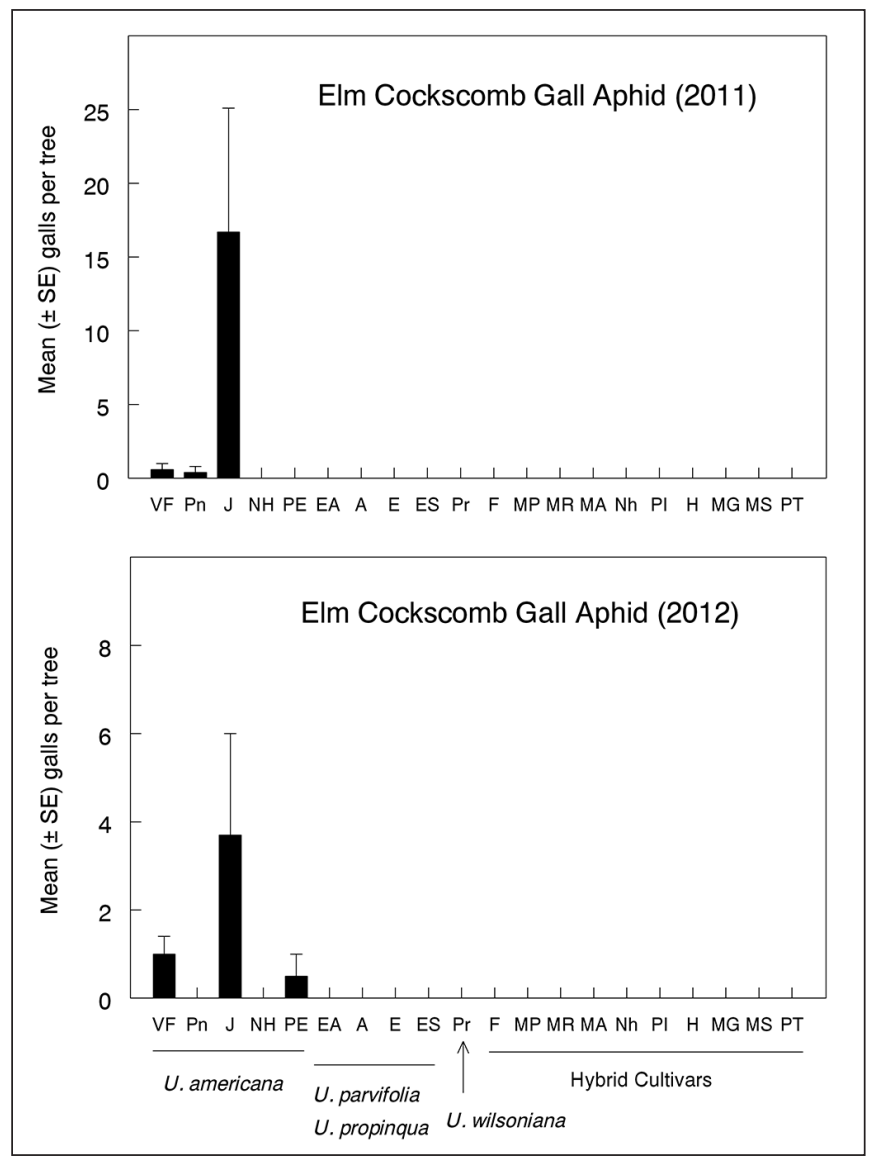

Figure 7. Elm cockscomb gall aphid was only found on American elms, among which its abundance differed each year (KruskalWallis, $P<0.001$ ). 
Table 2. Insect resistance ratings for elm species, hybrids, and cultivars evaluated in the National Elm Trial, Lexington, Kentucky, U.S., 2006-2012.

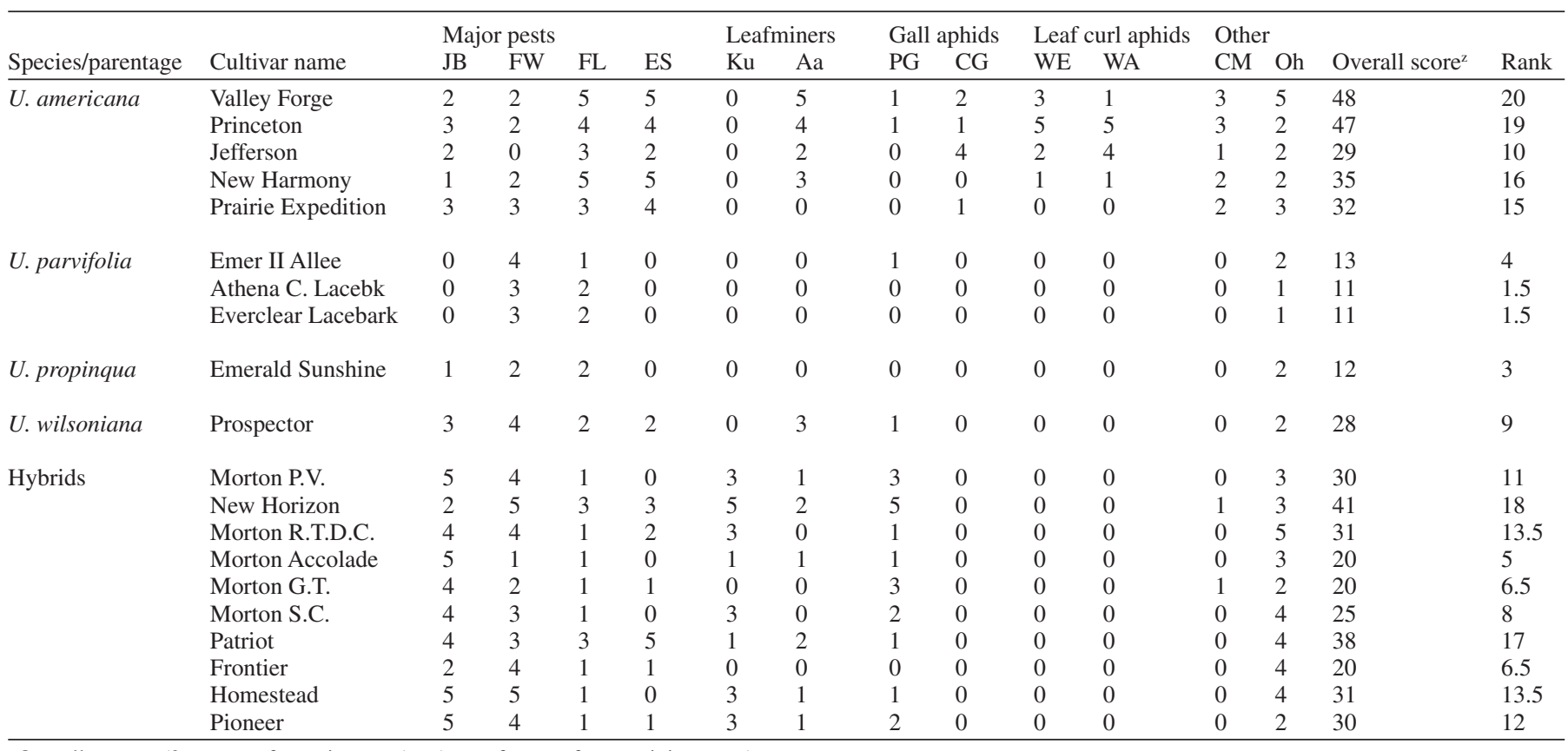

${ }^{2}$ Overall score $=(2 \times$ scores for major pests $)+($ sum of scores for remaining pests $)$.

NOTE: Pest abbreviations: JB, Japanese beetle; FW, European elm flea weevil; FL, European fruit lecanium; ES, European elm scale; Fu, Kaliofenusa ulmi; Aa, Agromyza aristata; PG, pouch gall; CG, cockscomb gall; WE, woolly elm aphid; WA, woolly apple aphid; CM, cottony maple scale; Oh, Oedophrys hilleri. Sources: Condra et al.

2010 and this paper.

to select DED-resistant elms needing minimal inputs to maintain a healthy, attractive tree. Cultivars of the Asian species $U$. parvifolia and $U$. propinqua, in particular, are relatively resistant to most insect pests under Kentucky conditions.

Acknowledgments. We thank J. Hartman and E. Dixon (University of Kentucky [UK] Plant Pathology Dept.) for establishing the UK National Elm Trial plot and allowing us access to the trees. R.S. Anderson (Canadian Museum of Nature, Ottawa) identified $O$. hilleri voucher specimens that are deposited in the UK Insect Collection, and Stephen Cresswell (Buckhannon, WV) loaned a photo of that species. We thank J. Larson, A. Kesheimer, and D. Lee for assisting with weevil sampling. This is paper 13-08-007 of the Kentucky Agricultural Experiment Station.

\section{LITERATURE CITED}

Analytical Software. 2008. Statistix version 9.0; User's manual. Analytical Software, Tallahassee, Florida, U.S.

Brasier, C.M., and M.D. Mehrotra. 1995. Ophiostoma himal-ulmi sp. Nov., a new species of Dutch elm disease fungus endemic to the Himalayas. Mycological Research 99:205-215.

Brown, M.W., and C.R. Mathews. 2009. Biology of Oedophrys hilleri (Faust) (Coleoptera: Curculionidae): A potential new pest of peach in the eastern United States. Entomological News 120:185-193.

Condra, J.M., C.M. Brady, and D.A. Potter. 2010. Resistance of landscapesuitable elms to Japanese beetle, gall aphids, and leaf miners, with notes on life history of Orchestes alni and Agromyza aristata in Kentucky. Arboriculture \& Urban Forestry 36:101-109.

Dreistadt, S.H., and K.S. Hagen. 1994. European elm scale (Homoptera: Eriococcidae) abundance and parasitism in northern California. PanPacific Entomologist 70:240-253.
Gibb, T.J., C.M.F. Pierce, and R.D. Waltz. 2005. A synopsis of insect activity in Indiana during 2005. Proceedings of the Indiana Academy of Science 116:42-49.

Hodges, A.C., and G. Hodges. 2001. Notes on members of the Vespidae foraging on honeydew secretions from the European fruit lecanium, Parthenolecanium corni (Bouche). Journal of Entomological Science 36:312-314

Hubbes, M. 1999. The American elm and Dutch elm disease. Forestry Chronicle 75:265-273.

Jacobi, W., J. Klett, and J. Walla. 2009. National Elm Trial overview. $<$ http://treehealth.agsci.colostate.edu/research/nationalelmtrial/ NationalElmTrial.htm>

Johnson, W.T., and H.H. Lyon. 1988. Insects That Feed on Trees and Shrubs, 2nd edition. Cornell Univ. Press, Ithaca, New York, U.S.

Merkle, S.A., G.M. Andrade, C.J. Nairn, W.A. Powell, and C.A. Maynard. 2007. Restoration of threatened species: A noble cause for transgenic trees. Tree Genetics \& Genomes 3:111-118.

Patch, E.M. 1910. Gall aphids of the elm. Maine Agricultural Experiment Station Bulletin 181, Orono, Maine, U.S.

Raupp, M.J., A.B. Cumming, and E.C. Raupp. 2006. Street tree diversity in eastern North America and its potential for tree loss to exotic borers. Arboriculture \& Urban Forestry 32:297-304.

Smalley, E.B., and R.P. Guries. 1993. Breeding elms for resistance to Dutch elm disease. Annual Review of Phytopathology 31:325-352.

Vanek, S.J., and D.A. Potter. 2010. Ant exclusion to promote biological control of soft scales (Hemiptera: Coccidae) on landscape plants. Environmental Entomology 39:1829-1837. 
Daniel A. Potter (corresponding author)

Department of Entomology

S-225 Agricultural Science Cntr. N

University of Kentucky

Lexington, Kentucky 40546-0091, U.S.

dapotter@uky.edu

Carl T. Redmond

Department of Entomology

S-225 Agricultural Science Cntr. N

University of Kentucky

Lexington, Kentucky 40546-0091, U.S.

ctredm00@uky.edu
Zusammenfassung. Der Nationale Ulmen-Versuch ist ein kooperatives Projekt, um die Eignung von Landschaften für Ulmenkrankheitsresistente Ulmenarten in verschiedenen Regionen von den Vereinigten Staaten zu testen. Forscher bewerteten in Zentral-Kentucky über sieben Jahre 20 Kultivare von Amerikanischen, Asiatischen und Hybridulmen auf eine relative Widerstandsfähigkeit oder Anfälligkeit gegenüber mehreren Insektenschädlingen. Bewertungen von Japankäfer, Europäischem Ulmenrüssler (EEFW) und verschiedenen anderen Schädlingen wurden kürzlich veröffentlicht. Die vorliegende Studie berichtet über Daten von sieben zusätzlichen Schädlingen, einschließlich Honigtau-ausscheidende Schildläuse (Parthenolecanium corni, Eriococcus spuria, and Pulvinaria innumerabilis), blattverkrümende Wollläuse und gallenbildende Läuse (Eriosoma spp.), (Colopha ulmicola) und ein invasiver Rüsselkäfer (Oedophrys hilleri), die vorher nicht als Ulmenschädlinge bekannt waren. Die Bewertungen für alle 12 der beobachteten Insekten werden hier summiert. Die meisten $U$. americana Kultivare waren relative anfällig für Schildläuse und Wollläuse, Eriosoma spp. während C. ulmicola nur Amerikanische Ulmen besiedelt. Die Besiedlung durch $O$. hilleri ist ein neuer Rekord für Kentucky. Die adulten Insekten, die von Mitte bis Ende Sommer aktiv sind, beißen Löcher in die Blattränder. Kultivare von den Asiatischen Arten $U$. parvifolia und $U$. propinqua, einschließlich 'Athena Classic Lacebark,' 'Everclear Lacebark,' 'Emer II Allee,' und 'Emerald Sunshine' wurden top-bewertet bei der Rsistenz gegenüber Insekten. Sie waren praktisch schädlingsfrei außer Blattschäden durch den Ulmenrüssler, der bei allen Ulmen Schaden verursachte. Die InsektenWiderstandsfähigkeit sollte bei der Einführung von Ulmen in urbane Landschaften berücksichtigt werden. Diese Daten können Stadtförstern, Landschaftsplanern und anderen helfen, die Einführung von Ulmen in urbane Landschaften durch Selektion von relativ schädlingsfreien Kultivaren, die nur minimale Aufwendungen für Schädlingsbekämpfung erfordern, durchzuführen.

Resumen. El Ensayo Nacional del Olmo es un proyecto de cooperación para evaluar la idoneidad de olmos resistentes a la enfermedad holandesa del olmo (Ulmus spp.) en varias regiones de los Estados Unidos. Los investigadores evaluaron 20 cultivares de olmos americanos, asiáticos, e híbridos de relativa resistencia o susceptibilidad a múltiples plagas de insectos en el centro de Kentucky por más de siete años. La valoración para el escarabajo japonés, gorgojo de olmo europeo (EEFW), y varias otras plagas se publicaron previamente. Este trabajo presenta datos para siete plagas adicionales, incluyendo insectos mielosos (Parthenolecanium corni, Eriococcus spuria y Pulvinaria innumerabilis), áfidos distorsionadores de la hoja y pulgones de manzana lanudos (Eriosoma spp.), áfidos del olmo (Colopha ulmicola), y un gorgojo invasivo (Oedophrys hilleri), que no se conoce previamente que dañe a los olmos. Se resumen los rangos para las 12 de las plagas monitoreadas. La mayoría de los cultivares de $U$. americana fueron relativamente susceptibles a las escamas de insectos y del mismo modo, Eriosoma spp. y C. ulmicola sólo infestaron los olmos americanos. $O$. hilleri es un nuevo récord para Kentucky. Sus adultos, activos de mediados a finales del verano, mastican los bordes de las hojas. Los cultivares de la especie asiática $U$. parvifolia y U. propinqua, incluyendo 'Athena Lacebark Classic', 'Everclear Lacebark', 'Emer Allee II' y 'Esmeralda Sunshine', fueron clasificados con la más alta resistencia a los insectos. Estuvieron casi libres de plagas a excepción de daño foliar por EEFW, al cual casi todos los olmos fueron susceptibles. La resistencia a los insectos se debe considerar al reintroducir olmos a los paisajes urbanos. Los datos pueden ayudar a los silvicultores de la ciudad, paisajistas y otros al reintroducir olmos a los paisajes urbanos para seleccionar cultivares relativamente libres de plagas que requieran insumos mínimos para el control de insectos. 